\title{
Effect of the use of golden mussel flour contaminated with lead as a source of calcium on the performance of broilers
}

\author{
Utilização de farinha de Mexilhão Dourado contaminado com \\ chumbo como fonte de cálcio sobre o desempenho de frangos de \\ corte
}

\author{
Lucas Wachholz ${ }^{1 *}$; Ricardo Vianna Nunes ${ }^{2}$; Affonso Celso Gonçalves Junior²; \\ Cinthia Eyng ${ }^{2}$; Leandro Dalcin Castilha ${ }^{3}$; Edinan Hagdon Cirilo ${ }^{1}$; Jomara Broch ${ }^{1}$; \\ Cleison de Souza ${ }^{1}$
}

\begin{abstract}
The objective of this study was to evaluate the use of lead contaminated golden mussel flour (GMF) as a source of calcium for broiler chickens from 14 to 42 days of age and to verify the probable effects on performance, tissue contamination, blood parameters, $\mathrm{Pb}$ digestibility, and bone quality. The experiment was conducted in a completely randomized design (DIC), with four levels of $\mathrm{Pb}$ contamination (71.33, $147.55,223.78$, and $300 \mathrm{mg} \mathrm{kg}^{-1} \mathrm{~Pb}$ ) in GMF, with five replicates and three birds per experimental unit. Sixty-four-day-old Cobb male broilers housed in metabolism cages were used. GMF was added to rations instead of calcitic limestone. The zootechnical variables were evaluated: feed intake, weight gain, and feed conversion, as well as the digestibility of nutrients. In addition, the serum biochemistry of the birds transaminases, total bilirubin, calcium, and phosphate was studied and the concentration of lead in the tissues and the bone quality of the birds was determined. The tibia was collected for evaluation of bone quality. The levels of $\mathrm{Pb}$ contamination in the golden mussel did not change the performance of the birds $(\mathrm{P} \geq 0.05)$ or the $\mathrm{Pb}$ levels in the muscle Pectoralis major, skin, liver, feather, bones, and serum, or the serum levels of ALT, GGT, and total bilirubin, however, there was an effect of $\mathrm{Pb}$ levels $(\mathrm{P}<0.01)$ on AST concentrations. $\mathrm{Pb}$ levels altered the values $(\mathrm{P}<0.01)$ of the apparent digestible $\mathrm{Pb}$ and the coefficient of apparent digestibility of $\mathrm{Pb}$, with an increasing linear effect. There was no effect $(\mathrm{P} \geq 0.05)$ on bone stiffness, however flexibility and bone strength were altered $(\mathrm{P}<0.05)$. Serum $\mathrm{Ca}$ and $\mathrm{P}$ concentrations did not show changes $(\mathrm{P} \geq 0.05)$ due to the use of $\mathrm{Pb}$ levels in GMF. In this study, it can be observed that the use of GMF with $\mathrm{Pb}$ up to $300 \mathrm{mg} \mathrm{kg}^{-1}$ as a source of Ca in broiler diets does not alter performance, however the use of GMF contaminated with $\mathrm{Pb}$ above $73.33 \mathrm{mg} \mathrm{kg}^{-1}$ promotes contamination of the tissues of the animals with $\mathrm{Pb}$, making it impossible to consume the birds. It was concluded that the increase in $\mathrm{Pb}$ concentrations in GMF increases the digestibility and metabolism of this metal and causes an increase in the production of AST by the liver. Pb levels in GMF above $214.11 \mathrm{mg} \mathrm{kg}^{-1}$ impair bone strength and flexibility.
\end{abstract}

Key words: Food. Poultry. Pollutants. Digestibility. Alternative ingredient. Transaminases.

\footnotetext{
${ }^{1}$ Discentes, Programa de Pós-Graduação em Zootecnia, Universidade Estadual do Oeste do Paraná, UNIOESTE, Cândido Rondon, PR, Brasil. E-mail: lucaswach@hotmail.com; edinancirilo@hotmail.com; brochjomara@yahoo.com.br; cleisondsz@ hotmail.com

2 Profs., UNIOESTE, Cândido Rondon, PR, Brasil. E-mail: nunesrv@hotmail.com; affonso133@hotmail.com; cinthiaeyng@ hotmail.com

3 Prof., Universidade Estadual de Maringá, UEM, Maringá, PR, Brasil. E-mail: leandrocastilha@hotmail.com

* Author for correspondence
} 


\section{Resumo}

Objetivou-se avaliar o uso da farinha de mexilhão dourado (FMD) contaminada com chumbo como fonte de cálcio para frangos de corte de 14 a 42 dias de idade e verificar prováveis efeitos no desempenho, contaminação de tecidos, parâmetros sanguíneos, digestibilidade de $\mathrm{Pb}$ e qualidade óssea. O experimento foi conduzido num delineamento inteiramente casualizado (DIC), sendo estudados quatro níveis de contaminação de $\mathrm{Pb}\left(71,33 ; 147,55 ; 223,78\right.$ e $300 \mathrm{mg} \mathrm{kg}^{-1}$ de $\left.\mathrm{Pb}\right)$ na FMD, cinco repetições e três aves por unidade experimental. Foram utilizados 60 frangos de corte, machos, Cobb, com 14 dias de idade, alojados em gaiolas de metabolismo. A FMD foi adicionada às rações em substituição ao calcário calcítico. As variáveis zootécnicas foram avaliadas - consumo de ração, ganho de peso e conversão alimentar; bem como a digestibilidade de nutrientes. Ainda, estudou-se a bioquímica sérica das aves transaminases, bilirrubina total, cálcio e fosfato; a concentração de chumbo nos tecidos e a qualidade óssea das aves. A tíbia foi coletada para avaliação da qualidade óssea. Os níveis de contaminação com $\mathrm{Pb}$ no mexilhão dourado não alteraram o desempenho das aves $(\mathrm{P} \geq 0,05)$, bem como os teores de $\mathrm{Pb}$ no músculo Pectoralis major, pele, fígado, pena, ossos e soro e nos teores séricos de ALT, GGT e bilirrubina total, porém houve efeito dos níveis de $\mathrm{Pb}(\mathrm{P}<0,01)$ sobre as concentrações de AST. Os níveis de $\mathrm{Pb}$ alteram os valores $(\mathrm{P}<0,01)$ de $\mathrm{Pb}$ digestível aparente e coeficiente de digestibilidade aparente de $\mathrm{Pb}$, havendo efeito linear crescente. ão ocorreu efeito $(\mathrm{P} \geq 0,05)$ sobre a rigidez óssea, mas a flexibilidade e resistência óssea foi alterada $(\mathrm{P}<0,05)$. As concentrações séricas de $\mathrm{Ca}$ e $\mathrm{P}$ não mostraram alterações $(\mathrm{P} \geq 0,05)$ pelo uso de níveis de $\mathrm{Pb}$ na FMD. Neste estudo pode ser observado que a utilização de FMD com $\mathrm{Pb}$ em até $300 \mathrm{mg} \mathrm{kg}^{-1}$ como fonte de $\mathrm{Ca}$ em dietas de frangos de corte não altera o desempenho, porém a utilização de FMD contaminada com $\mathrm{Pb}$ acima de $73,33 \mathrm{mg} \mathrm{kg}^{-1}$ promove contaminações dos tecidos dos animais com $\mathrm{Pb}$, impossibilitando assim o consumo das aves. Concluiu-se que o aumento nas concentrações de $\mathrm{Pb}$ na FMD aumenta a digestibilidade e metabolismo deste metal e provoca aumento na produção de AST pelo fígado. Níveis de Pb na FMD acima de 214,11 $\mathrm{mg} \mathrm{kg}{ }^{-1}$ prejudicam a resistência e a flexibilidade óssea.

Palavras-chave: Alimentação. Aves. Contaminantes. Digestibilidade. Ingrediente alternativo. Transaminases.

\section{Introduction}

The golden mussel is a bivalve belonging to the Mytilidae family and is a species of exotic character; it was accidentally introduced to Brazil and has invaded many of the rivers. This causes problems for the turbines of hydroelectric and water transport networks, which has generated the expenses for their removal and the maintenance of the equipment. An infestation of the golden mussel occurred in the reservoir of the hydroelectric plant of ITAIPU, located in the state of Paraná (CANZI et al., 2014), and caused serious problems in the work environment. Thus, these molluscs act by filtering the water for nutrients, metals, and other contaminants present in the aquatic environment where they live (ANTONIO et al., 2017).
According to Simkiss (1993), the shell of the golden mussel is a natural source of toxic metals and has an affinity for some metals, including lead $(\mathrm{Pb})$. This affinity is due to an approximation of the radii of two elements and to the fact of both directions of the same electric charge. This can be attributed to one of the main types of binding in the outer layer, which favors adaptation to the same binding sites (WANG et al., 2015).

In order to reduce the size of the year by halogen gold to study the influence of weight for animal feed as a pet has become an alternative, i.e., an ingredient for animal feed, replacing calcitic limestone in formulations (BAYERLE et al., 2017).

According to Bayerle et al. (2017), a golden mussel flour (GMF) meal has a high $\mathrm{Ca}$ content 
( $30.55 \%)$. This is one of two macronutrients required during the growth phase for muscle contraction, the activation of enzyme systems, hormone secretion, the transmission of nerve impulses, and blood coagulation.

The presence of contaminants of gold and especially heavy metal might be the main limiting factor for the use of these in animal diets. Another aggravating factor that hinders the use of this is a shortage of canisters in Brazil, which leads us to demand more $\mathrm{Pb}$ in the diets administered to animals (WACHHOLZ et al., 2017).

In order to implement a new ingredient in broiler diets, evaluations must be carried out to verify the presence of contaminants that affect the food and, consequently, the final consumer. Therefore, it is possible to carry out studies aiming to evaluate the possibility of using golden blood in the feeding of broilers without contaminating the birds with any kind of toxic metal (WACHHOLZ et al., 2017).

The objective of this study was to analyze the zootechnical performance, nutrient digestibility, biochemistry, and bone quality of broilers fed diets containing gold mussel flour contaminated with lead.

\section{Material and Methods}

Golden mussels were collected on the banks of the reservoir of the ITAIPU hydroelectric plant, in the municipality of Marechal Cândido Rondon, PR. They were dried in the sun, ground in a hammer mill (sieve with a $4 \mathrm{~mm}$ mesh), and stored. Samples of the mussel meal were collected for the determination of lead $(\mathrm{Pb})$, calcium $(\mathrm{Ca})$, and phosphorus $(\mathrm{P})$ levels, using nitroperchloric digestion (AOAC, 2005) and determination by flame retardant atomic absorption spectrometry. The values determined were 71.33 mg kg${ }^{-1}$ of $\mathrm{Pb}, 3.98 \mathrm{mg} \mathrm{kg}^{-1}$ of $\mathrm{P}$, and $30.64 \mathrm{mg} \mathrm{kg}^{-1}$ of Ca.

After quantification of the $\mathrm{Ca}, \mathrm{P}$, and $\mathrm{Pb}$ content, an experimental test was performed. All procedures were authorized by the Animal Experimentation Ethics Committee and practical lessons from UNIOESTE (Protocol 04/2017 CEUA).

From 1 to 14 days of age, the birds were raised under a bed of wood, receiving an initial feed formulated with corn and soybean meal (Table 1), which followed the nutritional levels proposed by Rostagno et al. (2011), and water at will.

Table 1. Composition and nutritional values of experimental diets.

\begin{tabular}{|c|c|c|}
\hline \multirow{2}{*}{ Ingredient } & \multicolumn{2}{|c|}{ Composition (\%) } \\
\hline & Growth (14-28 days) & Termination (28-42 days) \\
\hline Corn grain & 55.608 & 57.197 \\
\hline Soybean meal & 36.498 & 33.028 \\
\hline Soy oil & 3.800 & 4.854 \\
\hline Monobloccal Phosphate & 1.528 & 1.653 \\
\hline Gold Mussel & 1.185 & 1.096 \\
\hline Common Salt & 0.483 & 0.478 \\
\hline DL-Methionine (99\%) & 0.307 & 0.252 \\
\hline Biolys $(54,6 \%)$ & 0.338 & 0.266 \\
\hline L-threonine (98\%) & 0.068 & 0.036 \\
\hline Vitamin supplement ${ }^{1}$ & 0.010 & 0.010 \\
\hline Mineral suplement ${ }^{2}$ & 0.050 & 0.050 \\
\hline Choline chloride $(60 \%)$ & 0.060 & 0.060 \\
\hline
\end{tabular}




\begin{tabular}{lcc} 
continuation & & \\
Antioxidant $^{3}$ & 0.010 & 0.010 \\
Surmax $^{4}$ & 0.005 & 0.005 \\
Coxistac $^{5}$ & 0.050 & 0.050 \\
Celite & 0.000 & 1.000 \\
\hline Nutrient & \multicolumn{2}{c}{ Calculated composition } \\
\hline Metabolizable energy (kcal/kg) & 3.050 & 3.150 \\
Crude protein (\%) & 21.182 & 19.780 \\
Digestible Lysine (\%) & 1.217 & 1.099 \\
Digestible methionine + cystine (\%) & 0.876 & 0.791 \\
Threonine & 0.897 & 0.714 \\
Tryptophan & 0.273 & 0.222 \\
Calcium (\%) & 0.841 & 0.837 \\
Available phosphorus (\%) & 0.401 & 0.418 \\
Sodium (\%) & 0.210 & 0.208 \\
Potassium (\%) & 0.830 & 0.776 \\
\hline
\end{tabular}

${ }^{1}$ Vitamin supplement for birds (Lote BR00014639), Levels of Guarantee per Kilogram product: Vit. A (min) 9000000.00 UI, Vit. D3 (min) 2500000.00 UI, Vit. E (min) 20000.00 UI, Vit. K3 (min) 2500.00 mg, Vit. B1 (min) 1500.00 mg, Vit. B2(min) $6000.00 \mathrm{mg}$, Vit. B6(min) $3000.00 \mathrm{mg}$, Vit. B12 (min) $12000.000 \mathrm{mg}$. Pantothenic acid (min) $12 \mathrm{~g}$, Niacin (min) 25g, Folic acid (min) $800.00 \mathrm{mg}$, Biotin (min) $60.0 \mathrm{mg}$, Selenium (min) $250.0 \mathrm{mg}$; ${ }^{2}$ Mineral supplement for birds (Lote BR00013863), Levels of Warranty Per Kilogram of Product: Copper ( $\mathrm{min}$ ) 20g, Iron (min) 100g, Manganese (min) 160g, Cobalt (min) $2000.0 \mathrm{mg}$, Iodine (min) $2000.0 \mathrm{mg}$, Zinc (min) 100g; ${ }^{3} \mathrm{BHT} ;{ }^{4}$ Avilamycin; ${ }^{5}$ Salinomycin $12 \%$.

A total of 60 male broilers, aged 14 days and weighing $393.95 \pm 14.12 \mathrm{~g}$, were vaccinated against Marek, Gumboro, Avian Bouba, and Infectious Bronchitis and housed in $50 \mathrm{~cm}^{2}$ cages with three birds per experimental unit. The experimental design was completely randomized, with four treatments (71.33, 147.55, 223.78, and $300 \mathrm{mg} \mathrm{kg}^{-1}$ of $\mathrm{Pb}$ in GMF) ter were supplied ad libitum throughout the experiment and the lighting was $24 \mathrm{~h}$ light with the aid of lamps.

At 14, 28, and 42 days of age, all birds and feed were weighed for the determination of weight gain, feed intake, and feed conversion.

At 42 days of age, the birds were fasted for six hours before collecting blood via a brachial puncture. After this procedure, the blood was centrifuged (2500 rpm) and the serum separated and stored at $-20{ }^{\circ} \mathrm{C}$ for aspartate aminotransferase (AST) assays (ASSL-0430) and the determination of the levels of alanine aminotransferase (ALT) (ALSL-0410), gamma glutamyl transferase (GIS-0600), total bilirubin (BITD-0600), calcium (CALA-0600), and phosphorus (PHOS-0600). The determinations were performed using commercial kits (Flexor EL 200, Elitech, Paris, France) using an automated spectrophotometer (Elitech EL 200).

After the collection of blood, all birds were sacrificed by cervical dislocation and subsequent bleeding for the collection of skin (around the chest), muscle (Pectoralis major) breast meat, feathers, bone (femur), and liver for the determination of $\mathrm{Pb}$ content. For the quantification of $\mathrm{Pb}$ in the tissues and in the serum, the methodology previously mentioned for the mussel was used.

The thigh was boned to obtain the tibia. To determine the bone stiffness and strength, the Brookfield CT3 Texture Analyzer was used with a base that supports the regions of the bony epiphyses, and a force of $5 \mathrm{~mm} \mathrm{~s}^{-1}$ with a load of $200 \mathrm{kgf}$ was applied to the central region of the bone (diaphysis) and values were expressed in millimeters $(\mathrm{mm})$ and kilogram of force (kgf), respectively. Flexibility was 
given in $\mathrm{kgf} \mathrm{cm}$ and calculated by the relationship between bone strength and rigidity (strength/ stiffness).

The concentration of lead in rations and feces $\left(\mathrm{mg} \mathrm{kg}^{-1}\right)$ was determined by means of individual trays on the last day of the experiment, and the insoluble acid ash (Celite $\left.{ }^{\circledR}\right)$ was used to calculate the indigestibility factor(IF). The obtained data were used in the formulas described for the determination of the apparent metabolizable $\mathrm{Pb}(\mathrm{AM} \mathrm{Pb})$ and the coefficient of apparent digestibility of $\mathrm{Pb}$ (ADC $\mathrm{Pb}$ ), and the values were expressed on the basis of dry matter. $\mathrm{mg} \mathrm{kg}^{-1}=\mathrm{Pb} / \mathrm{kg}$ feed $\left(\mathrm{mg} \mathrm{kg}^{-1}\right)-(\mathrm{Pb} / \mathrm{kg}$ excreted $\left.\left(\mathrm{mg} \mathrm{kg}^{-1}\right) \times \mathrm{IF}\right)$. $\left(\mathrm{Pb}\right.$ in the feces $\left(\mathrm{mg} \mathrm{kg}^{-1}\right)$ $\left(\mathrm{Pb}\right.$ in the diet $\left.\left.\left(\mathrm{mg} \mathrm{kg}^{-1}\right)\right) \times \mathrm{IF}\right) / \mathrm{Pb}$ in the diet $) \times 100$ (SAKOMURA; ROSTAGNO, 2016).

The data were analyzed using the GLM procedure of the SAS software (SAS Institute, 2018) and an analysis of variance and subsequent polynomial regression was used analyze the lead toxicity levels at $5 \%$ significance.

\section{Results and Discussion}

In Brazil, there are no laws regulating the amounts of $\mathrm{Pb}$ metal that may be present in food and feed additives supplied to animals, therefore the industry standards are based on the values of the European regulations found in Directive 2005/87/EC of 5 December 2005 (EUROPEAN COMMISSION REGULATION, 2005) concerning undesirable substances in feeding stuffs, which sets the limit for $\mathrm{Pb}$ at $10 \mathrm{mg} \mathrm{kg}^{-1}$, which is lower than that obtained in GMF, which was $71.33 \mathrm{mg} \mathrm{kg}^{-1}$.

The use of GMF contaminated with increasing $\mathrm{Pb}$ levels in diets did not influence $(\mathrm{P} \geq 0.05)$ the performance of the birds from 14 to 42 days of age (Table 2). These results corroborate the work of Wang et al. (2015), who did not observe a significant effect of $\mathrm{Pb}$ contamination levels from 1.03 to 1000 $\mathrm{mg} \mathrm{kg} \mathrm{kg}^{-1}$ in the diets supplied to sea cucumbers on their development.

Table 2. Performance of broilers $( \pm \mathrm{SD})$ fed with inclusion of GMF contaminated with $\mathrm{Pb}$ in the diet.

\begin{tabular}{lcccc}
\hline $\mathrm{Pb}\left(\mathrm{mg} \mathrm{kg}^{-1}\right)$ & $\mathrm{FW}(\mathrm{g})$ & $\mathrm{WG}(\mathrm{g})$ & $\mathrm{FI}(\mathrm{g})$ & $\mathrm{FCR}\left(\mathrm{g} \mathrm{g}^{-1}\right)$ \\
\hline 71.33 & $2677 \pm 147$ & $2252 \pm 147$ & $3794 \pm 192$ & $1.688 \pm 0.06$ \\
147.55 & $2765 \pm 130$ & $2373 \pm 124$ & $3897 \pm 125$ & $1.648 \pm 0.04$ \\
223.78 & $2563 \pm 370$ & $2265 \pm 98$ & $3826 \pm 126$ & $1.684 \pm 0.07$ \\
300.00 & $2737 \pm 70$ & $2336 \pm 78$ & $3955 \pm 105$ & $1.696 \pm 0.04$ \\
\hline Mean & 2686.0 & 2307.0 & 3868.4 & 1.679 \\
\hline MSE & 35.73 & 24.00 & 29.20 & 0.01 \\
\hline $\mathrm{P}$ & 0.560 & 0.145 & 0.823 & 0.739 \\
\hline
\end{tabular}

FW (Final weight); WG (Weight gain); FI (Feed intake); FCR (Feed conversion rate); MSE (Mean standard error); P (P value).

The high concentration of lead present in GMF and its contamination with increasing levels of lead nitrate were not sufficient to cause toxicity in the birds or to negatively affect the performance of the birds. This is probably due to the inclusion of this flour at approximately $1.00 \%$ and its dilution with the other feed ingredients which made the lead concentration relatively low and insufficient to cause injury to the birds or compromise performance.
There was no effect $(\mathrm{P} \geq 0.05)$ of the $\mathrm{Pb}$ levels in the mussel on the concentrations of $\mathrm{Pb}$ in the studied tissues (Table 3 ). The concentration of $\mathrm{Pb}$ in all tissues studied was higher than that allowed by ANVISA (BRASIL, 1965), which is $0.20 \mathrm{mg} \mathrm{kg}^{-1}$. It is important to note that the muscle Pectoralis major (breast), liver, and skin are edible tissues and all treatments presented concentrations of $\mathrm{Pb}$ above that allowed by ANVISA, thus making it impossible to 
use them for human consumption. It should also be borne in mind that bones and feathers, although not edible, are transformed into animal feed ingredients, and can thus enter the human food chain as well.

The ingestion of 1 to $2 \mathrm{mg}$ of $\mathrm{Pb}$ during one week, according to Coutinho et al. (2004), is sufficient to cause chronic toxicity by $\mathrm{Pb}$, which is termed as saturnism. Thus, when the lowest concentration of $\mathrm{Pb}$ found in the present study was $5.22 \mathrm{mg} \mathrm{kg}^{-1}$, it was concluded that the use of GMF in animal feed under the conditions of the present study should not be permitted, since it contaminates poultry products and consequently causes toxicity for humans.
Considering also that the lower concentration of $\mathrm{Pb}$ present in GMF produced values of $\mathrm{Pb}$ in the bird muscle of $7.73 \mathrm{mg} \mathrm{kg}^{-1}$, GMF with these values or higher cannot be used in poultry feed, since its use at $1 \%$ contaminates the carcass and has been shown to have a high bioaccumulation power.

The inclusion of $1 \%$ GMF contaminated with $71.33 \mathrm{mg} \mathrm{kg}^{-1}$ of $\mathrm{Pb}$ in the diet is equivalent to the addition of $0.71 \mathrm{mg} \mathrm{kg}^{-1}$ of $\mathrm{Pb}$ in the diet from the golden mussel. In the analysis of feed consumption, it was verified that the average ration consumption obtained in the present study reached $2.70 \mathrm{mg}$ of $\mathrm{Pb}$ per bird from the GMF used in the diet.

Table 3. Concentrations of $\mathrm{Pb}( \pm \mathrm{SD})$ in the tissues of broiler chickens fed GMF contaminated with $\mathrm{Pb}$ levels.

\begin{tabular}{lcccccc}
\hline \multirow{2}{*}{$\mathrm{Pb}\left(\mathrm{mg} \mathrm{kg}^{-1}\right)$} & \multicolumn{7}{c}{ Concentrations of $\mathrm{Pb}$ in $\mathrm{m} \mathrm{kg} \mathrm{k}^{-1}$} \\
\cline { 2 - 7 } & Pectoralis major & Skin & Liver & Bone & Feathers & Serum \\
\hline 71.33 & $7.73 \pm 0.89$ & $15.46 \pm 1.30$ & $5.44 \pm 1.85$ & $22.47 \pm 2.31$ & $13.18 \pm 0.99$ & $10.20 \pm 0.84$ \\
147.55 & $7.99 \pm 0.82$ & $15.36 \pm 0.35$ & $5.22 \pm 1.44$ & $21.88 \pm 1.64$ & $10.81 \pm 0.61$ & $10.20 \pm 1.30$ \\
223.78 & $8.87 \pm 1.17$ & $14.80 \pm 0.48$ & $5.35 \pm 1.65$ & $23.57 \pm 1.19$ & $10.64 \pm 0.95$ & $12.75 \pm 1.09$ \\
300.00 & $8.26 \pm 0.38$ & $14.17 \pm 0.65$ & $5.26 \pm 1.58$ & $21.48 \pm 2.73$ & $11.54 \pm 0.56$ & $13.40 \pm 1.52$ \\
\hline Mean & 8.14 & 14.95 & 5.32 & 22.35 & 11.54 & 11.64 \\
\hline MSE & 0.176 & 0.231 & 0.038 & 0.335 & 0.409 & 0.719 \\
\hline $\mathrm{P}$ & 0.160 & 0.150 & 0.997 & 0.877 & 0.144 & 0.432 \\
\hline
\end{tabular}

MSE (Mean standard error); P (P value).

The concentration of $\mathrm{Pb}$ in the liver can be explained by the fact that it is the main organ acting in the metabolism of nutrients in the animals. Thus, toxic substances such as heavy metals will have contact with this organ and consequently contaminate it.

Bones are the main sites of accumulation of minerals in animals and owing to this, they have a higher concentration of $\mathrm{Pb}$ than the other tissues of chickens. It should be noted that this toxic metal competes for the same binding sites used by calcium.

Animals with high amounts of the metal $\mathrm{Pb}$ present in the tissues should not be destined for human consumption since, according to Souza et al.
(2017), this metal has a cumulative and carcinogenic effect, thus causing damage to health.

The toxic heavy metals present a cumulative effect on the animals' bodies (BAYERLE, et al., 2017), and even though this study was only carried out with birds from 14 to 42 days of age, this period was sufficient to generate high contamination in the birds.

The $\mathrm{Pb}$ levels in the diet were not sufficient to cause alterations $(P \geq 0.05)$ in the levels of ALT, GGT, or total bilirubin in the blood (Table 4). A mean value of 8.6 IU L-1 of ALT was found in this study, which is within the range recommended by Borsa et al. (2006) for broilers at 42 days of age 
(between 4 and 14 IU L-1). For GGT, a mean value of $11.35 \mathrm{IU} \mathrm{L}-1$ was found, which is below the mean age range reported by Borsa et al. (2006) (17 to 24 IU L-1). Therefore, the GGT values found in this study should be considered normal, since the lower the blood concentration of this enzyme, the lower the chances of liver disorders.

The $\mathrm{Pb}$ levels in GMF caused alterations in AST values, with a linear effect $(\mathrm{P}<0.05)$ of $\mathrm{Pb}$ concentrations present in GMF on the AST concentration. The increase in this variable corroborates the results of Omobowale et al. (2014) who carried out a study carried on mice experiencing $\mathrm{Pb}$ toxicity. The elevation in AST concentrations in the blood of the birds might be associated with the toxic levels of $\mathrm{Pb}$ present in the GMF, and according to Thrall et al. (2015), indicates signs of liver or muscle damage. However, the mean concentration of AST found in this work $\left(241.3 \mathrm{IU} \mathrm{L}^{-1}\right)$ is similar to the normal range for broilers at 42 days of age obtained by Borsa et al. (2006) of 202 to 229 IU $\mathrm{L}^{-1}$, which is also similar to the result obtained by Gonçalves et al. (2014) of $251.6 \mathrm{IU} \mathrm{L}^{-1}$.

Table 4. ALT, AST, GGT and Bilirubin ( \pm SD) contents in broilers fed GMF with levels of Pb contamination.

\begin{tabular}{lcccc}
\hline $\mathrm{Pb}\left(\mathrm{mg} \mathrm{kg}^{-1}\right)$ & AST $\left(\mathrm{IU} \mathrm{L}^{-1}\right)$ & ALT $\left(\mathrm{IU} \mathrm{L}^{-1}\right)$ & GGT $\left(\mathrm{IU} \mathrm{L}^{-1}\right)$ & Total Bilirubin $\left(\mathrm{mg} \mathrm{dL}^{-1}\right)$ \\
\hline 71.33 & $176.6 \pm 42$ & $9.0 \pm 2.10$ & $10.2 \pm 3.76$ & $0.30 \pm 0.14$ \\
147.55 & $265.2 \pm 25$ & $7.2 \pm 1.72$ & $10.4 \pm 3.01$ & $0.39 \pm 0.15$ \\
223.78 & $206.8 \pm 49$ & $8.0 \pm 3.85$ & $12.2 \pm 1.72$ & $0.60 \pm 0.25$ \\
300.00 & $316.6 \pm 47$ & $10.2 \pm 2.79$ & $12.6 \pm 0.80$ & $0.54 \pm 0.13$ \\
\hline Mean & 241.3 & 8,6 & 11.35 & 0.46 \\
\hline MSE & 22.182 & 0.447 & 0.470 & 0.050 \\
\hline $\mathrm{P}$ & 0.015 & 0.464 & 0.104 \\
\hline \multicolumn{5}{c}{ Regression Equations } \\
\hline AST & $153.224160+0.474380 \mathrm{~Pb}$ \\
\hline
\end{tabular}

MSE (Mean standard error); $\mathrm{P}$ (P value); $\mathrm{R}^{2}$ (determination coefficient).

The mean value of total bilirubin was $0.46 \mathrm{mg}$ $\mathrm{dL}^{-1}$, a value similar to that reported in Silva et al. (2007), who described a mean value of $0.41 \mathrm{mg} \mathrm{dL}$ ${ }^{1}$, which is indicative of normal data for bilirubin in the present study.

These results of the blood parameters, even with increasing levels of AST, indicated that the levels of $\mathrm{Pb}$ present in the experimental diets did not negatively affect the hepatic metabolism of the birds, thus the use of $300 \mathrm{mg} \mathrm{kg}^{-1}$ of $\mathrm{Pb}$ in GMF does not cause hepatic toxicity in the birds.

There was an increasing linear effect of $\mathrm{Pb}$ inclusionlevels $(\mathrm{P}<0.01)$ on the apparent digestibility coefficient $(\mathrm{ADC} \mathrm{Pb})$ and metabolizable $(\mathrm{AM} \mathrm{Pb})$ values of $\mathrm{Pb}$ (Table 5). This high $\mathrm{Pb}$ digestibility might be associated with the high $\mathrm{Pb}$ concentrations found in chicken tissues demonstrated in this study. 
Table 5. Pb digestibility ( $\pm \mathrm{SD}$ ) of diets with inclusion of GMF contaminated with $\mathrm{Pb}$ levels.

\begin{tabular}{lcc}
\hline \multirow{2}{*}{$\mathrm{Pb}\left(\mathrm{mg} \mathrm{kg}^{-1}\right)$} & \multicolumn{2}{c}{ Digestibility of $\mathrm{Pb}$} \\
\cline { 2 - 3 } 71.33 & $\mathrm{AM} \mathrm{Pb}\left(\mathrm{mg} \mathrm{kg}^{-1}\right)$ & $\mathrm{ADC} \mathrm{Pb}(\%)$ \\
147.55 & $8.52 \pm 3.14$ & $31.98 \pm 4.16$ \\
223.78 & $14.44 \pm 1.51$ & $45.65 \pm 4.79$ \\
300.00 & $15.82 \pm 1.72$ & $61.11 \pm 6.64$ \\
\hline Mean & $23.36 \pm 1.58$ & $78.20 \pm 5.28$ \\
\hline MSE & 15.53 & 54.23 \\
\hline $\mathrm{P}$ & 4.055 & 15.420 \\
\hline & $<0.01$ & $<0.01$ \\
\hline AM Pb & Regression Equations & $\mathrm{R}^{2}$ \\
$\mathrm{ADC} \mathrm{Pb}$ & $4.060758+4.5892 \mathrm{~Pb}$ & 0.94 \\
\hline $\mathrm{AST}$ & $16.696647+0.2021 \mathrm{~Pb}$ & 0.99 \\
\hline
\end{tabular}

MSE (Mean standard error); P (P value); $\mathrm{R}^{2}$ (determination coefficient).

The levels of $\mathrm{Pb}$ contamination present in GMF had no effect on bone stiffness $(\mathrm{P} \geq 0.05)$ (Table 6). This fact should be highlighted since according to Currey (2003), the greater the bone stiffness, the more susceptible bone will be to fractures. However, there was a quadratic effect of $\mathrm{Pb}$ levels in GMF on bone strength and flexibility $(\mathrm{P}<0.05)$.
The maximum bone strength was reached with the inclusion of GMF with $218.11 \mathrm{mg} \mathrm{kg}^{-1}$ of $\mathrm{Pb}$, and the maximum bone flexibility was achieved with the inclusion of GMF contaminated with 214.11 $\mathrm{mg} \mathrm{kg}{ }^{-1}$ of $\mathrm{Pb}$, at concentrations of $\mathrm{Pb}$ higher than these there was a worsening of the values of these variables.

Table 6. Bone rigidity, resistance and flexibility values $( \pm$ SD) of animals fed diets containing GMF containing levels of $\mathrm{Pb}$.

\begin{tabular}{|c|c|c|c|}
\hline $\mathrm{Pb}\left(\mathrm{mg} \mathrm{kg}^{-1}\right)$ & Rigidity (mm) & Resistance (Kgf) & Flexibility $\left(\mathrm{Kgf} \mathrm{mm}^{-1}\right)$ \\
\hline 71.33 & $3.97 \pm 0.32$ & $8.69 \pm 0.25$ & $21.01 \pm 0.39$ \\
\hline 147.55 & $4.06 \pm 0.20$ & $9.05 \pm 0.43$ & $23.45 \pm 0.42$ \\
\hline 223.78 & $3.96 \pm 0.27$ & $9.63 \pm 0.34$ & $24.29 \pm 0.31$ \\
\hline 300.00 & $3.97 \pm 0.09$ & $9.14 \pm 0.25$ & $23.03 \pm 0.52$ \\
\hline Mean & 3.99 & 9.13 & 22.95 \\
\hline MSE & 0.035 & 0.257 & 0.967 \\
\hline $\mathrm{P}$ & 0.880 & $<0.01$ & $<0.01$ \\
\hline & \multicolumn{2}{|c|}{ Regression Equations } & $\mathrm{R}^{2}$ \\
\hline Resistance & \multicolumn{2}{|c|}{$7.664203+0.016114 \mathrm{~Pb}-0.000037 \mathrm{~Pb}^{2}$} & 0.82 \\
\hline Flexibility & \multicolumn{2}{|c|}{$16.937423+0.068090 \mathrm{~Pb}-0.000159 \mathrm{~Pb}^{2}$} & 0.99 \\
\hline
\end{tabular}

MSE (Mean standard error); $\mathrm{P}$ (P value); $\mathrm{R}^{2}$ (determination coefficient). 
According to Oliveira et al. (2014), the minerals that make up the bones confer this rigidity, whereas the collagen fibers that form part of the composition of this tissue give it a certain flexibility, which is essential since it helps to prevent bone fractures. Resistance and flexibility are the most important factors that prevent bone fractures.

$\mathrm{Ca}$ is the most abundant mineral in the bones of animals, and the amount of this mineral found in bone tissue represents 98 to $99 \%$ of the Ca found in the body (SAKOMURA et al., 2014). If we associate the importance of this element for the structure of the bone tissue with the strong interaction between $\mathrm{Pb}$ and $\mathrm{Ca}$, it is known that $\mathrm{Pb}$ has the capacity to participate in the physiological processes that involve Ca (WANG et al., 2015), which can be attributed to the fact that the two chemical elements in question have a similar valence, this $\mathrm{Pb}$ can concentrate in the bones of the contaminated animals and alter the physical properties of their fabric.

With the increase in $\mathrm{Pb}$ levels in the GMF there was probably a bone de-calcification in the birds, which corroborates with the results for bone resistance and flexibility. This might be due to the occurrence of $\mathrm{Ca}$ mobilization in the bone structure when the $\mathrm{Ca}$ concentrations available in the bloodstream cannot withstand the demands of the body for the mineral, and this can compromise bone structure, leaving the bones fragile.

The problems of decalcification or symptoms of calcium deficiency in the bone structure can cause problems such as rickets, which have characteristic features such as swollen joints, an enlargement of the bony ends and rubberized nozzles (SOUZA; VIEITES, 2014). Other diseases, such as osteomalacia, are indicative of calcium deficiency that might compromise the development of older birds (SAKOMURA et al., 2014). However, no symptoms related to calcium deficiency were observed in the broilers during the course of this study, evidencing that GMF can be used as a source of calcium for birds.

The use of GMF contaminated with $\mathrm{Pb}$ did not influence $(\mathrm{P}>0.05)$ the serum concentrations of $\mathrm{Ca}$ or P (Table 7).

Table 7. Serum $\mathrm{Ca}$ and $\mathrm{P}( \pm \mathrm{SD})$ concentrations of animals fed diets with inclusion of GMF contaminated with different levels of $\mathrm{Pb}$.

\begin{tabular}{lcc}
\hline $\mathrm{Pb}\left(\mathrm{mg} \mathrm{kg}^{-1}\right)$ & $\mathrm{Ca}(\mathrm{mg} \mathrm{dL}$ & \\
\hline 71.33 & $4.44 \pm 0.64$ & $\mathrm{P}\left(\mathrm{mg} \mathrm{dL}^{-1}\right)$ \\
147.55 & $4.54 \pm 0.95$ & $3.65 \pm 0.80$ \\
223.78 & $5.64 \pm 1.21$ & $3.43 \pm 0.40$ \\
300.00 & $5.54 \pm 1.07$ & $3.71 \pm 0.57$ \\
\hline Mean & 5.04 & $3.91 \pm 0.88$ \\
\hline MSE & 0.550 & 3.67 \\
\hline $\mathrm{P}$ & 0.215 & 0.135 \\
\hline
\end{tabular}

MSE (Mean standard error); P (P value).

The importance of assessing blood calcium is also due to the fact that $\mathrm{Pb}$, during its distribution in the animal, follows the calcium metabolic pathway. In addition, $\mathrm{Pb}$ affects enzymatic reactions where $\mathrm{Ca}$ plays important roles (CHIU et al., 2009), leading to problems in the animals, such as affecting bone resistance and being associated with osteoporosis (ALMEIDA et al., 2015).

$\mathrm{Pb}$ is directly linked to changes in development, vitamin D metabolism, and erythrocyte 
protoporphyrin, which is directly linked to the formation of heme groups (ATSDR, 2007), and these are responsible for transporting minerals such as $\mathrm{Ca}$ and $\mathrm{P}$ and might also interfere with $\mathrm{Pb}$ transport.

There is a lack of legislation that limits the concentrations of toxic heavy metals $(\mathrm{Pb})$ in ingredients used in the formulation of animal diets, which means that companies do not give as much importance to the control of contamination by this element, which has high potential environmental contamination and a high risk when introduced into the animal feed chain and can therefore be introduced into the human food chain. In the wild, lead usually occurs in mineral sources used in animal diets, as in the case of this study where it is present in the source of $\mathrm{Ca}$.

It is known that the control of $\mathrm{Pb}$ in the diets only occurs because it is easily absorbed by the animals and, as a consequence, might lead to the contamination of the meat and or products derived from the birds, thus generating concern for the industrial sector, since the products of animal origin have a $\mathrm{Pb}$ concentration limit established by ANVISA (BRASIL, 1965), thus contamination with toxic metal can lead to losses.

\section{Conclusions}

The presence of levels of up to $300 \mathrm{mg} \mathrm{kg}^{-1}$ of $\mathrm{Pb}$ in GMF provided as a dietary ingredient does not affect the performance of broiler chickens, however, the concentration of $71.33 \mathrm{mg} \mathrm{kg}^{-1}$ of this metal in GMF provides high levels of lead in the poultry carcass.

The higher the $\mathrm{Pb}$ concentration in the rations, the higher the digestibility, the metabolization, and the higher the production of AST by the liver. Bone flexibility and strength are affected by $\mathrm{Pb}$ present in the diet and levels above $214.11 \mathrm{mg} \mathrm{kg}^{-1}$ impair bone tissue.

\section{Acknowledgments}

To CNPq for the financial support to the project.

\section{References}

AGENCY FOR TOXIC SUBSTANCES AND DISEASE REGISTRY - ATSDR. Toxicological profile for lead. Atlanta, GA: Department of Health and Human Services, 2007. $582 \mathrm{p}$.

ALMEIDA, M. E. F.; TAGLIASSACHI, P. M.; TAVARES, R. O.; LUJAN, D. L. B. Reversão da osteoporose: uma realidade possivel. Journal of Health \& Biological Sciences, Fortaleza, v. 3, n. 4, p. 245-248, 2015. DOI: 10.12662/2317-3076jhbs.v3i4.191.p245248.2015

ANTONIO, L. L. C. P. S.; CAPILÉ, H. E.; DUARTE, R. Mexilhão dourado (Limnoperna fortunei) como bioindicador aquático. Pesquisa \& Educação a Distância, São Gonçalo, v. 4, n. 8, 2017, p. 1-14.

ASSOCIATION OF OFFICIAL ANALYTICAL CHEMISTS - AOAC. Official methods of analysis of the Association Analytical Chemists. 18. ed. Gaithersburg, Maryland: AOAC, 2005.

BAYERLE，D. F.; NUNES， R. V.; GONÇALVES JUNIOR, A. C.; WACHHOLZ, L.; SCHERER, C.; SILVA, I. M.; BRUXEL, T. M. O.; VARGAS JUNIOR, J. G. Golden mussel (Limnoperna fortunei) in feed for broiler chicks using tannin as a sequestrant of toxic metals. Semina: Ciências Agrárias, Londrina, v. 38, n. 2, p.843854, 2017. DOI: $10.5433 / 1679-0359.2017 \mathrm{v} 38$ n2p843

BRASIL. Decreto n 55.871 de 26 de março de 1965. Modifica o Decreto $n^{\circ} 50.040$, de 24 de janeiro de 1961, referente a normas reguladoras do emprego de aditivos para alimentos, alterado pelo Decreto $\mathrm{n}^{\circ} 691$, de 13 de março de 1962. Diário Oficial [da] União, Brasília, 9 abr. 1965. Seção 1, pt. 1, p. 3611.

BORSA, A.; KOHAYAGAWA, A.; BORETTI, L. P.; SAITO, M. E.; KUIBIDA, K. Níveis séricos de enzimas de função hepática em frangos de corte de criação industrial clinicamente saudáveis. Arquivo Brasileiro de Medicina Veterinária e Zootecnia, Belo Horizonte, v. 58, n. 4 , p.675-677, 2006. DOI: 10.1590/S010209352006000400035

CANZI, C.; FIALHO, N.; BUENO, G. W. Monitoramento e ocorrência do mexilhão dourado (Limnoperna fortunei) na hidrelétrica da Itaipu binacional, Paraná (BR). Revista Ibero-Americana de Ciências Ambientais, Aracaju, v. 5 , n. 2 , p. $117-122$, 2014. DOI: $10.6008 /$ SPC21796858.2014.002.0011 
CHIU, T. Y.; TENG, H. C.; HUANG, P. C.; KAO, F. J.; YANG, D. M. Dominant role of Orai1 with STIM1 on the cytosolic entry and cytotoxicity of lead ions. Toxicologycal Sciences, Reston, v. 110, n. 2, p.353-362, 2009. DOI: 10.1093/toxsci/kfp099

COUTINHO, F. M. B; GOMES, A. S.; TEIXEIRA, V. G.; Resinas poliméricas para separação e pré-concentração de chumbo. Química Nova, São Paulo, v. 27, n. 2, p. 754762, 2004. DOI: $10.1590 / \mathrm{S} 0100-40422004000500015$

CURREY, J. D. The many adaptation of bone. Journal of Biomechanics, Rotterdam, v. 36, n. 10, p. 1487-1495, 2003.

EUROPEAN COMMISSION REGULATION. Directive n 2005/87/Ce of Commission of December. Official Journal of European Union, 1318/19-1318/24, 2005.

GONÇALVES, F. G.; ZANINI, S. R.: GUERRA, A. F. Q. G.; GONÇALVES, E. P.; COLNAGO, G. L.; FEITOSA, M. L. Utilização de pimenta rosa como um aditivo natural na dieta sobre o desempenho de frangos de corte. Revista Brasileira de Saúde e Produção Animal, Salvador, v. 15 , n. 1, p. 28-38, 2014. DOI: $10.1590 /$ S1519-99402014000100007

OMOBOWALE, T. O.; OYAGBEMI, A. A.; AKINRINDE, A. S.; SABA, A. B.; DARAMOLA, O. T.; OGUNPOLU, B. S.; OLOPADE, J. O. Failure of recovery fron lead induced hepatoxicity and disruption of erythrocute antioxidant defence system in winstar rats. Environmental Toxicology and Pharmacology, v. 37, n. 3, p. 1202-1211, 2014. DOI: 10.1016/j.etap.2014.03.002

OLIVEIRA, A. F. G.; BRUNO, L. D. G.; MARTINS, E. N.; DE MORAES GARCIA, E. R.; MONTEIRO, A. C.; PAULA LEITE, M. C. de; POZZA, P. C.; SANGALI, C. P. Effect of stocking density and genetic group on mineral composition and development of long bones of broilers. Semina: Ciências Agrárias, v. 35, n. 2, p. 10231034, 2014. DOI: 10.5433/1679-0359.2014v35n2p1023

SAKOMURA, N. K.; ROSTAGNO, H. S. Métodos de pesquisa em nutrição de monogástricos. Jaboticabal: FUNEP, 2016. 262 p.
SAKOMURA, N. K.; VILAR DA SILVA, J. H.; PERAZZOCOSTA, F. G.; FERNANDES, J. B. K.; HAUSCHILD, E. U. Nutrição de não-ruminantes. Jaboticabal: FUNEP, 2014. 678 p.

SAS INSTITUTE INC - SAS. SAS University edition: installation guide for windows. Cary, NC: SAS Institute, 2018. 24 p.

SILVA, P. R. L.; FREITAS NETO O. C.; LAURENTIZ A. C.; JUNQUEIRA O. M.; FAGLIARI J. J. Blood serum components and serum protein test of Hybro-PG broilers of different ages. Revista Brasileira de Ciência Avícola, Campinas, v. 9, n. 4, p. 229-232, 2007. DOI: 10.1590/ S1516-635X2007000400004

SIMKISS, K. Amorphous minerals in biology. Bulletin Institute Oceanographic, San Diego, v. 14, n. especial, p. 49-54, 1993.

SOUZA, C. S.; VIEITES, F. M. Vitamin D3 and its metabolities for broilers. Archivos de Zootecnia, Córdoba, v. 63 , n. 241 , p. 11-24, 2014. DOI: 10.5713 / ajas.2012.12455

SOUZA, V. F.; NOBREGA, M. A. S.; PONTES, M. S. Musgos como bioindicadores de metais pesados no ambiente. Acta Biomedica Brasiliensia, Itaperuna, v. 8, n. 2, p. 13-22, 2017. DOI: 10.18571/acbm.136

THRALL, M. A. Hematologia e bioquímica clínica veterinária. São Paulo: Editora Roca, 2015. 688 p.

WACHHOLZ, L.; NUNES, R.V.; BROCH, J.; SOUZA, C. Possibilidade do uso de mexilhão dourado contaminado com metais tóxicos em dietas para frangos de corte. Revista Colombiana de Ciência Animal, Sincelejo, v. 9, n. 2, p. 227-235, 2017. DOI: $10.24188 /$ recia.v9.n2.2017.562

WANG, H.; WANG, Z.; JIAO, P.; ZHOU, X.; YANG, D.; YOUNG, Z. W.; WANG, L. Redistribution of subcellular calcium and its effect on apoptosis in primary cultures of rat proximal tubular cells exposed to lead. Toxicology, v. 333, n. 3 , p. 137-146, 2015. DOI: 10.1016/j. tox.2015.04.015 
